\title{
THE NOCTUID MOTHS OF THE GENERA PALINDIA AND DYOMYX.
}

\author{
By Harrison G. Dyar, \\ Custodian of Lepidoptera, United States National Museum.
}

These strikingly colored Noctuids have long been favorites with collectors. They are best known under the name Palindia of Guenée. The Dyomyx have been generally associated with the Palindia, and are apparently allied. Dyomyx has a very long third joint to the palpi and presents none of the modifications of the hind tibiæ of the male, so general in Palindia. Some of the species have been frequently interchanged between the genera.

The first species of Palindia made known were by Cramer, under the general terms Phalæna Noctua and Phalæna Geometra. Hübner ranged them in two genera, Eulepidotis and Phrygionis. The type of the latter is generally considered to be cultaria Hübner (= politata Stoll, not politia Cramer), the first species, a Geometrid. Of the former, the type is ilyrias Cramer, the first species, fixed by Butler (1892), a Palindia. Guenée next established Palindia and Dyomyx. Walker made no new genera in this group. Butler divided Palindia in three parts, using Eulepidotis for the green ones, Palindia for the white ones, and Phrygionis for the yellow ones. Bar placed them all in Palindia, included Dyomyx as closely related, if not a subgenus, but separated the species with curved outer line under the name Calydia. The species will be treated here as done by Guenée under two names, but it will be necessary to substitute the older Eulepidotis for Palindia.

Three species have been reported in the United States, Eulepidotis dominicata Guenée from southern Texas, where it may even be established, E. micca Druce, recently reported from Texas by Barnes and McDunnough, and Dyomyx merricki Holland from Pennsylvania, where it was probably accidentally imported on tropical fruit.

Nothing is known of the larvæ or life history of any of the rather numerous species. One hundred and three species are here considered of Eulepidotis and twenty of Dyomyx. 


\section{Genus EULEPIDOTIS Hübner.}

Eulepidotis Hய̈BNER, Verz. bek. Schmett., 1816, p. 291. Type, illyrias Cramer (recte ilyrias) (first species); ilyrias specified by Butler, Ent., 1892, p. 189.

Palindia GuenéE, Spec. Gen., 1852, vol. 6, p. 274 . Type, hemileuca Guenée (first species); julianata Stoll specified by Butler, Ent., 1892, p. 189.

Calydia Bar, Ann. Soc. Ent. France (5), 1875, vol. 5, p. 291. Type, bourgaulti Bar (first species); here specified.

Table of the species.

1. Outer line strongly depressed, forming an arc from tornus to middle of costa. 2 Outer line not so curved . . . . . . . . . . . . . . . . . . . . . . . 7

2. Dark markings forming detached spots; angular-edged spots at apex, median

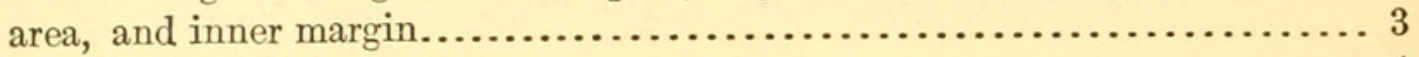

Without detached dark spots..................................... 4

3. Color pale ocher................................. metalligera Butler.

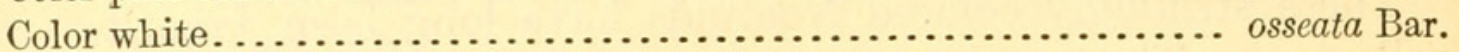

4. A dark brown velvety shade beneath the outer arcuate line............... 5

No dark shade beneath the outer arcuate line...................... 6

5. Discal area violaceous and roseate; hind wing ocherous shaded.. ornata Dognin. Discal area without violet tint; hind wing fuscous............ hemithea Druce.

6. Orange ocher; vertical line within outer arcuate line catenulate, without bordering metallic scales........................... bourgaulti Bar.

Dull ocher grayish; this line a row of pale spots, edged without by metallic blue

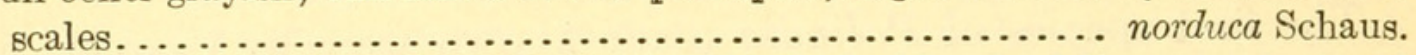

7. Ground color not white; forewing crossed by 3 double-edged lines, or the basal

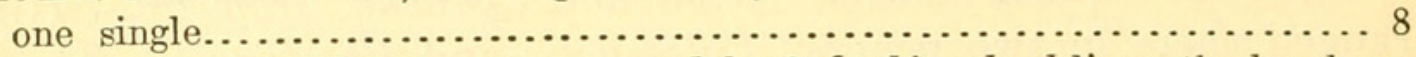

Ground color not white; forewing crossed by 2 double-edged lines, the basal one of the normal 3 obsolete..................................... 45

Ground color white; forewing with 3 bands converging on tornus, the two outer generally suffused to the margin, leaving a single oblique band across middle.. 52 Ground color dark brown; a silvery white band or spots across middle of wing... 64

Ground color white; at least thorax and base of wings; markings vertical, or not of 3 bands converging on tornus. . . . . . . . . . . . .

Ground color pale yellow with 2 parallel dark lines perpendicular to inner margin

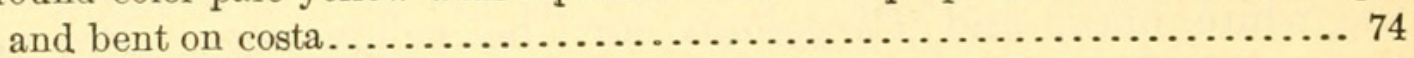

8. Lines regular, straight or curved, not crenulate or crumpled............. 9

Lines crenulate or crumpled................................. 42

9. Central line obsolescent, marked with metallic only on costa.............. 10

Central line developed like the others........................... 11

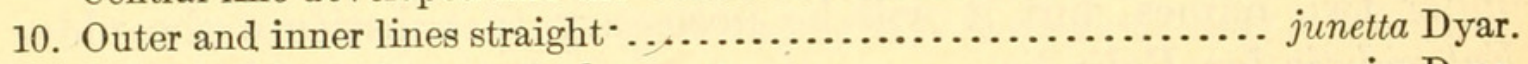

Outer and inner lines curved on costa.................. magica Dyar.

11. Ground color not green; subterminal metallic line present on forewing...... 12

No metallic subterminal line except in species with green ground color...... 26

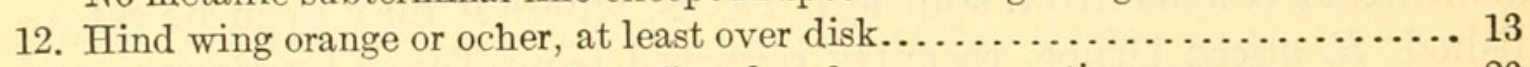

Hind wing fuscous, or largely suffused, only apex sometimes orange........ 20

13. Hind wing without dark patch at apex............................... 14

Hind wing with dark patch at apex.............................. 19

14. Lines of forewing with linear metallic edges . . . . . . . . . . . . . . . . 15

Lines of forewing with broad metallic edges........................ 16

15. Mark on hind wing single, large, blue.................... dives Butler.

Mark on hind wing of 2 oblique dashes and a patch of scales.......... emilia Bar.

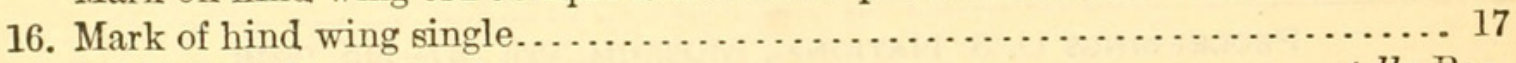

Mark of hind wing double................................ ste Bar. 
17. Metallic borders of lines leaden.

Metallic borders of lines, except subterminal, blue

suzetta Dyar.

18. Ground color yellowish orange. formosa Bar. Ground color reddish orange. crocoptera Felder and Rogenhofer.

19. Brighter orange, contrasted. corinna Cramer. Duller orange; fuscous markings more suffused........... prismatica Dyar.

20. Thorax and base of forewing suffused with green........... transcendens Dyar. Thorax and base of forewing orange to fuscous brown $\ldots \ldots \ldots \ldots \ldots \ldots \ldots \ldots .21$

21. Apex of hind wing orange to the edge.................. penumbra Dyar. Apex of hind wing, if orange marked, not to the edge................ 22

22. Thorax and base of forewing orange ocher................. regalis Butler. Thorax and base of forewing fuscous brown

23. Apex of hind wing with ocher patch; metallic lines of forewing distinct

selecta Dyar.

Apex without ocher patch; metallic lines narrow, less distinct............. 24

24. Apex of forewing with orange patch.................. austrina Schaus. Apex of forewing without such patch. 25

25. Dull, minutely squamose-strigate; lines scarcely orange-filled...... sabina Bar. Brighter, smoothly scaled; lines orange-filled ............ cœruleilinea Walker.

26. Lines broad, double-edged, filled with sordid orange shades.............. 27 Lines occluded or nearly so, narrow, without distinct double edges; forewing

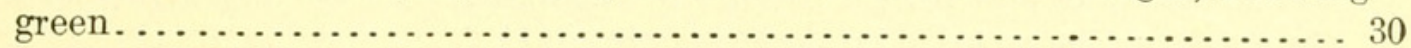

27. Inner line broad like the others, the 3 subparallel lines running to inner margin 28 Inner line reduced, single, the others tending to converge on tornus......... 29

28. Wings mottled with green; no subterminal dots............. reticulata Bar. Wings not green; a row of subterminal dark dots............... mustela Druce.

29. Small; smooth gray; a whitish zigzag subapical shade......... addens Walker. Large; clouded; no subapical mark................... superior Guenée.

30. Hind wing fuscous with green patch on margin ............... anna Dyar. Hind wing broadly green, at least on disk .......................... 31

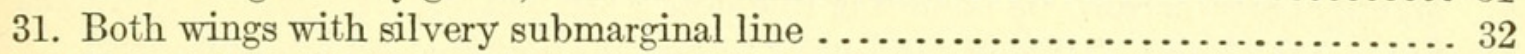

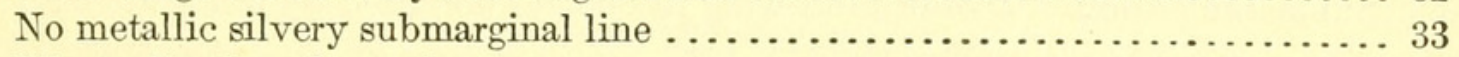

32. Silvery line broad, continuous $\ldots \ldots \ldots \ldots \ldots \ldots \ldots \ldots \ldots \ldots \ldots \ldots \ldots \ldots \ldots$ argentitinea Schaus. Silvery line slender, broken into dashes...................... reducens Dyar.

33. Hind wing with point or short tail on margin, marked with black in fringe... 34 Hind wing without point marked in the fringe, smoothly rounded or bluntly

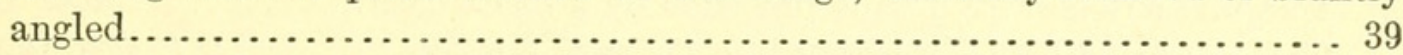

34. Wings beneath brown and ocher except near base..................... 35 Wings beneath largely green....................................... 37

35. Submedian fold of hind wing with a brown ray; apex of hind wing generally with a distinct brown patch............................ viridissima Bar. Submedian fold of hind wing without a brown ray; no apical patch........ 36 36. Smaller; markings of the wings beneath slight. chloris Bar. Larger; markings of the wings beneath distinct............... folium Schaus.

37. Hind wing with subapical orange patch and orange at tornus. . . . . . . . . . 38 Hind wing without orange, all pure green above and below..... glaucopasa Dyar.

38. Wings below largely brownish; male without fovea in cell of hind wing.

Wings below clear green; male with transparent fovea in cell of hind wing. sylpha Dyar.

39. Smaller; hind wing with little orange and that faint.................. 40 Larger; hind wing with large sharply marked orange patch at apex and tornus. . 41

40. Hind wing with small silver patch before tornus................ schedoglauca Dyar. Hind wing without this patch; a brown spot on margin............holoclera Dyar.

$34843^{\circ}$-Proc.N.M.vol.47-14-7 
41. Hind wing with an angle on margin; no silvery dot; a brown streak on submedian

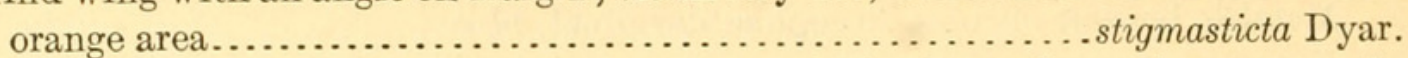
Hind wing without angle; a small silvery dot within the angle; no brown on sub-

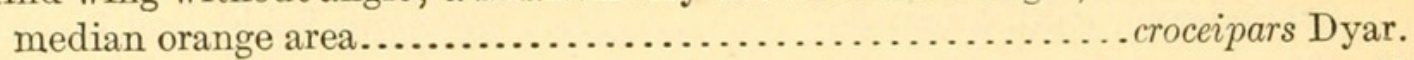

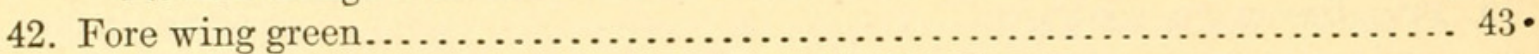

Fore wing dark, with white marks about middle of costa . . . . . . . . . . . 44

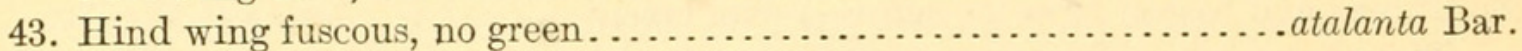
Hind wing with green at tornus and margin.................... erina Dyar.

44. Lines of fore wing regularly spaced...................... delecta Schaus. Lines of fore wing with the two inner approximated......... serpentifera Brabant.

45. Inner line traceable by dots..................................... 46

Inner line not traceable beyond costa.......................... 48

46. Costal edge marked with white, especially at inceptions of lines............ 47 No white on costal edge...................... striæpuncta Herrich-Schaffer.

47. Hind wing dull, violet patch not contrasted.................... ezra Druce. Hind wing bright; violet patch well contrasted.................. hebe Möschler.

48. Terminal space of clear pale yellow ground color....................... 49 Terminal space filled in with brown except on costa beyond outer line..... 50

49. Ground color very pale yellow........................ perducens Walker. Ground color distinctly straw yellow...................... affinis Schaus.

50. Transverse lines joined by a bar on inner margin............. julianata Stoll. Transverse lines separate on inner margin . . . . . . . . . . . . . . . . 51

51. Fore wing yellow except terminal space....................juncida Guenée. Fore wing all shaded with brown........................ var. mabis Guenée.

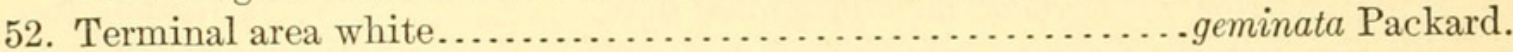
Terminal area brown, suffusing the two outer lines.................... 53

53. Fringe brown . . . . . . . . . . . . . . . . . . . . . . 54

Fringe white, at least at base centrally........................... 58

54. Marginal area broad, the bounding inner line inbent in the middle.......... 55 Marginal area narrow, its bounding line nearly straight................ 56

55. Submarginal dotted area of hind wing in orange, preceded by a minute dash.

fortissima Dyar. This area in ocher, preceded by a long dash............. dominicata Guenée.

56 . Oblique band joining outer area on tornus............... persimilis Guenée. Oblique band joining inner margin, separate from outer area........... 57

57. Marginal patch of hind wing preceded by a black dash............ nicæa Druce. This patch without preceding line, or very faintly............teligera Brabant.

58. Marginal area inbent in middle; hind wing with no yellow except on margin... 59 Marginal area straight or nearly so; hind wing frequently suffused with yellow. 60

59. Middle band very broad, white area reduced to narrow band on costal wedge.

Giddle band moderate; white area broad ...............suppura Dyar.

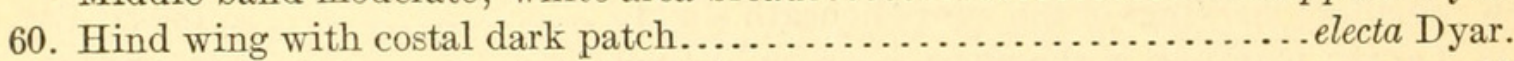

Hind wing without costal dark patch........................... 61

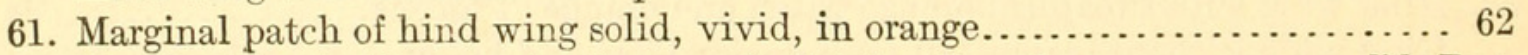
Marginal patch dilute, pale, the marginal dots relieved............. candida Bar.

62. Marginal band of fore wing rather broad............................. 63 Marginal band of fore wing narrow....................... santarema Walker.

63. Band of fore wing running to costa before middle, well separated from base.

rectimargo Guenée.

This band very oblique, joined to base by the costal dash.... metamorpha Dyar.

61. Inner band blue........................... albata Felder and Rogenhofer.

Inner band silvery white........................................ 65 
65. Costal half of hind wing whitish

Costa of hind wing with central pale patch at most.................... 66

ouocco Dyar.

66. Smaller; orange patches larger; submedian dark dash of hind wing generally doubled or hooked....................... guttata Felder and Rogenhofer.

Larger; orange patches small; submedian dash of hind wing single.

67. Outer portion of wings white like the inner.............................

Outer portion of fore wing filled in with dark brown, sharply limited..., .... 70

68. Two straight lines on fore wing converging on tornus............ detracta Walker. One angular line oblique on tornus, the others costal wedges or dots.

testaceiceps Felder and Rogenhofer.

Two irregular lines across wing, parallel, running to inner margin........ 69

69. Fringe on central third of outer margin of hind wing brown, but without preceding

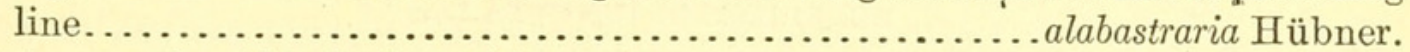

Outer margin of hind wing with short, central, brown, preceding line.

pulchella Bar.

70. Hind wing with long brown bar preceding gray metallic area before marginal

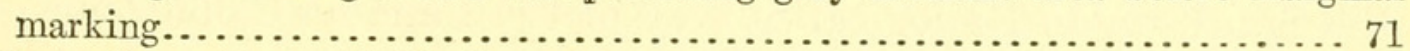

Hind wing with small black spot before metallic area, and a smaller dot near

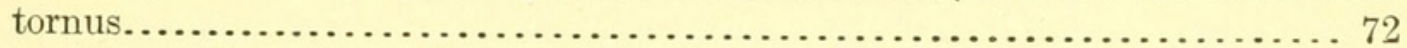

71. Base of fore wing white with costal dark patch and dot.........hemileuca Guenée. Base of fore wing filled in with brown to vein $1 \ldots \ldots \ldots \ldots \ldots$ microleuca Dyar.

72. Hind wing with no marginal ocellus..................... vincentiata Stoll. Hind wing with marginal ocellus and white streak ..................... 73

73. Termen divided in two colors by a wavy subterminal line........... ornata Bar. Termen all evenly dark, no subterminal line.............caudata Herrich-Schäffer.

74. Inner line of irregular large purple blotches................. hermura Schaus. Inner line fine and slender..................................... 75

75. Ground color pale yellow.................... modestula Herrich-Schäffer. Ground color darker yellow............................. micca Druce.

\section{EULEPIDOTIS METALLIGERA Butler.}

Phrygionis metalligera Butler, Trans. Ent. Soc. Lond., 1879, p. 32.

Calydia metalligera Druce, Biol. Cent.-Amer., Lep. Het., vol. 1, 1889, p. 316.

Described from the Amazons. Specimens are before me from Colombia, French Guiana, Panama, Costa Rica, and Mexico.

\section{EULEPIDOTIS OSSEATA Bar.}

Calydia osseata BAr, Ann. Soc. Ent. France (5), vol. 5, 1875, p. 293.

Unknown to me in nature. Bar's figure differs from metalligera Butler only in being white instead of yellow.

\section{EULEPIDOTIS ORNATA Dognin.}

Calydia ornata Dognin, Mém. Soc. Ent. Belg., vol. 18, 1911, p. 155.

I have a single specimen before me from Bolivia agreeing with Dognin's description.

EULEPIDOTIS HEMITHEA Druce.

Calydia hemithea Druce, Biol. Cent.-Amer., Lep. Het., vol. 1, 1889, p. 316.

Described from Panama. I have two specimens from Chiriqui before me. 
EULEPIDOTIS BOURGAULTI Bar.

Calydia bourgaulti BAR, Ann. Soc. Ent. France (5), vol. 5, 1875, p. 292.

Phrygionis setosa Butler, Trans. Ent. Soc. Lond., 1879, p. 31.

Described from French Guiana. I have specimens before me from that locality and others from Panama.

\section{EULEPIDOTIS NORDUCA Schaus.}

Calydia norduca Schaus, Ann. Mag. Nat. Hist. (7), vol. 8, 1901, p. 38.

The type is from Jalapa, Mexico. I have others from Mexico, Costa Rica, and Panama.

\section{EULEPIDOTIS JUNETTA Dyar. ${ }^{1}$}

This species from Tabernilla, Canal Zone, Panama, will be more fully described in a forthcoming report dealing with the results of the Smithsonian Biological Survey of the Panama Canal Zone.

\section{EULEPIDOTIS MAGICA, new species.}

Dark slaty brown, finely peppered over thorax and fore wings, the scales having bright tips as in sabina Bar, shading to orange brown over apex; three lines of metallic green, the inner bent subcostally, then slightly oblique, followed by brown; mesial line more oblique, lost below the subcosta except for a faint dark trace; outer line oblique above, less so below vein 5, running to tornus, preceded by orange at costa; a leaden subterminal line. Hindwing nearly black, without tail; three blue spots in a row along submedian fold, the middle one black outwardly, the outer marginal one nearly all black, raised; a slight black prominence on margin above this last,spot. Expanse, $23-25 \mathrm{~mm}$.

Cotypes.-One male, one female, No. 15697, U. S. Nat. Mus.; St. Jean and St. Laurent, Maroni River, French Guiana, October and November, 1904 (W. Schaus).

\section{EULEPIDOTIS DIVES Butler.}

Phrigionis dives Butlen, Trans. Ent. Soc. Lond., 1879, p. 30.

Palindia dives Druce, Biol. Cent.-Amer., Lep. Het., vol. 1, 1889, p. 317.

Three specimens are before me from French Guiana, identified by Schaus.

\section{EULEPIDOTIS EMILIA Bar.}

Palindia emilia BAR, Ann. Soc. Ent. France (5), vol. 5, 1875, p. 299.

Described from French Guiana, whence I have two specimens and another from Dutch Guiana.

\section{EULEPIDOTIS FORMOSA Bar.}

Palindia formosa BAr, Ann. Soc. Ent. France (5), vol. 5, 1875, p. 300.

I have two specimens from French Guiana, the type-locality. 
EULEPIDOTIS CROCOPTERA Felder and Rogenhofer.

Palindia crocoptera Felder and Rogenhofer, Reise Novara, Lep., pl. 111, fig. $18,1872$.

I have three specimens of this from French Guiana.

EULEPIDOTIS SUZETTA, new species.

Yellow, unusually clear; lines straight, dark ocherous, edged on one side by a fine brown line, on the other by a broad band of metallic bluish scales; inner line with colors reversed; mesial line more oblique than the others; a subterminal leaden line preceded by a brown line. Hindwing clear yellow; a rounded metallic blue spot on submedian fold, well before margin, at about outer third of wing; on the margin three silvery patches, marked by a few brown scales, the lower one opposite the submedian patch is the largest. Expanse, $24 \mathrm{~mm}$.

Type.-Male, Cat. No. 15698, U. S. Nat. Mus.; St. Jean, Maroni River, French Guiana, April, 1904 (W. Schaus).

The specimen bears a label "corinna Cr., fide B. M."; but Bar's identification must be respected since Cramer's figure is so poor as to be uncertain if considered alone.

\section{EULEPIDOTIS STELLA Bar.}

Palindia stella BAr, Ann. Soc. Ent. France (5), vol. 5, 1875, p. 297.

I have no specimens of this species, which seems very distinct, judging from Bar's figure.

\section{EULEPIDOTIS CORINNA Cramer.}

Phalæna Noctua corinna Cramer, Pap. Exot., vol. 1, 1779, p. 47, pl. 29, fig. H.

Palindia corinna BAR, Ann. Soc. Ent. France (5), vol. 5, 1875, p. 296.

Phrygionis quadrilineata KAYE, Trans. Ent. Soc. Lond., 1901, p. 123.

I have specimens from Trinidad, British and French Guianas, and Venezuela.

EULEPIDOTIS PRISMATICA, new species.

Dull ocher, shaded with sordid nearly all over the wings; lines double, the centers dull ocher, inner line blackish, outer metallic violet, but appearing dark leaden in most lights, inner line reversed; both mesial and outer lines bent more or less in the middle; reniform a dusky shade; submarginal line leaden; terminal row of dark dots. Hindwing with costa smoky, disk only dull orange; a curved streaked band with violet scales across disk; three silvery patches on margin preceded by black dots. Beneath rather uniformly light ocherous straw color. Expanse, 20-24 mm.

Cotypes.-One male, two females, Cat. No. 15699. U. S. Nat. Mus. St. Jean, Maroni River, French Guiana, July, 1904 (W. Schaus).

Close to corinna Cramer, but, I think, distinct. It is generally duller, less contrastingly colored, and beneath the uniform light ocherous tint is different from the bright yellow contrasted markings of corinna. 
EULEPIDOTIS TRANSCENDENS, new species.

Thorax, basal segment of abdomen, and basal space of fore wing pale glaucus green; fore wing lilacine brown, apical half yellow, forming a clear wedge on costa before outer line and a blotched area at apex; lines broad, double, orange filled, slender inner line dark brown, outer broad, metallic blue; subterminal line silvery; fringe dark. Hind wing nearly solidly fuscous; a yellow area in fringe below apex and at tornus; patch on submedian fold metallic blue, followed by minute lines to the silvery marginal patches, the lower of which has its black dots fused into a crescent. Expanse, 25-27 mm.

Cotypes.-Two males, one female, Cat. No. 15700, U. S. Nat. Mus.; St. Jean, Maroni River, French Guiana, July, 1904 (W. Schaus).

This species is abnormal in lacking entirely the hind tibial tufts of the male.

\section{EULEPIDOTIS PENUMBRA, new species.}

Dark brown; forewing rather roughly scaled, apex yellowish; lines double but rather narrow, curved, orange brown, but slightly relieved from the ground; metallic edges blue, narrow, that of midline obsolete below subcosta; subterminal line leaden. Hindwing with clear yellow apex, involving the fringe, the rest of the wing of color of forewing, shading to blackish on costal half; two raised patches of scales on submedian fold, with blue metallic tint, the outer one marginal and followed by a second smaller spot above; a dark line from subcostal dark region to inner submedian spot. Expanse, $27 \mathrm{~mm}$.

Type.-Female, Cat. No. 15701, U. S. Nat. Mus.; St. Jean, Maroni River, French Guiana, March, 1904 (W. Schaus).

\section{EULEPIDOTIS REGALIS Butler.}

Phrygionis regalis Butler, Trans. Ent. Soc. Lond., 1879, p. 31, note.

I have one specimen from French Guiana, identified by Schaus.

EULEPIDOTIS SELECTA, new species.

Forewing brown over orange under tint, which appears subapically in a triangular diffused area; lines orange brown, with slender dark inner edges and metallic blue outer ones (inner line reversed), inner and mesial lines straight, the mesial more oblique; outer line curved in upper half; subterminal line silvery; terminal dots black. Hindwing fuscous brown, a light patch near apex; disk with a reddish area, followed by a metallic blue band, then an area of black irrorations; three marginal silvery elongate patches with black dots. Beneath contrastingly marked, orange-yellow and fuscous, the apex of forewing broadly fuscous; hindwing with two streaks on costa. Expanse, $27 \mathrm{~mm}$.

Type.-Female, Cat. No. 15702, U. S. Nat. Mus.; Rockstone, Eissequibo River, Dutch Guiana, September, 1904 (W. Schaus).

Near corinna Cramer, more darkly shaded, the lines narrower and with slender metallic edges. 
EULEPIDOTIS AUSTRINA Schaus.

Palindia austriana Schaus, Ann. Mag. Nat. Hist. (8), vol. 7, 1911, p. 60.

The type and another specimen from the same locality are before me.

\section{EULEPIDOTIS SABINA Bar.}

Palindia sabina BAR, Ann. Soc. Ent. France (5), vol. 5, 1875, p. 301.

Seven specimens from French Guiana are before me.

\section{EULEPIDOTIS CERULEILINEA Walker.}

Palindia cœruleilinea Walker, Cat. Brit. Mus., Lep. Het., part 15, 1858, p. 1768.

Palindia corineta Felder and Rogenhofer, Reise Novara, Lep., 1872, pl. 111, fig. 2.

Palindia lucia BAr, Ann. Soc. Ent. France (5), vol. 5, 1875, p. 300.

A long series from the Guianas, Venezuela, Panama, Costa Rica, and Mexico is before me.

\section{EULEPIDOTIS RETICULATA Bar.}

Palindia reticulata BAR, Ann. Soc. Ent. France (5), vol. 6, 1876, p. 249.

Palindia diana Möschler, Verh. zool.-bot. Ges. Wien, vol. 30, 1880, p. 394.

Ten specimens from French and Dutch Guiana are before me.

EULEPIDOTIS MUSTELA Druce.

Palindia mustela Druce, Biol. Cent.-Amer., Lep. Het., vol. 2, 1889, p. 318.

Described from Mexico. I have three from there and one from Panama.

\section{EULEPIDOTIS ADDENS Walker.}

Palindia addens Walker, Cat. Brit. Mus., Lep. Het., part 15, 1858, p. 1768.

Described from Santo Domingo. I have three from Porto Rico, one from Santa Lucia, and one from Dominica.

\section{EULEPIDOTIS SUPERIOR Guenée.}

Palindia superior Guenée, Spec. Gen., vol. 6, 1852, p. 278.

Palindia dewitzii Möschler, Abh. Senck. nat. Ges., vol. 14, 1886, p. 196.

Palindia deva Druce, Biol. Cent.-Amer., Lep. Het., vol. 1, 1889, p. 320.

The description of superior is without locality; dewitzii is from Porto Rico and deva from Mexico and Panama. I have a long series from Mexico, Costa Rica, and Venezuela, none from the Antilles, though Möschler's description leaves no doubt of the identity of dewitzii. The species varies considerably in shading. Generally the ground color is uniform, but occasionally the terminal space is paler and without the purple shading, and again it is markedly darker than the rest of the wing.

\section{EULEPIDOTIS ANNA, new species.}

Green; apex of abdomen fuscous; forewing green, costal edge brown; three lines, slender, brown, oblique, the outer curved and doubled; fringe brown. Hindwing brown, shading paler on costa; a green streak each side of submedian fold, and a semicircular green 
patch on outer margin. Beneath pale, with brown shadings, no green. Expanse, $24 \mathrm{~mm}$.

Type.-Female, Cat. No. 15703, U. S. Nat. Mus.; St. Jean, Maroni River, French Guiana, July, 1904 (W. Schaus).

\section{EULEPIDOTIS ARGENTILINEA Schaus.}

Palindia argentilinea Schaus, Proc. U. S. Nat. Mus., vol. 30, 1906, p. 110.

Only the unique type is before me.

\section{EULEPIDOTIS REDUCENS, new species.}

Bright grass green, costa narrowly orange-brown, with blackish dots toward apex; inceptions of the three lines on costa brown, with dark edges; lines subparallel, approximate, bent subcostally, all running to inner margin, the mesial and outer ones approaching each other a little, all the lines narrower and less intense below; a subterminal silvery line, narrow and cut by the veins. Fringe brown tipped. Hindwing whitish on costal third, with subterminal silvery line as on fore wing; a slight prominence in the margin at vein 3 with a black dot preceded by silver and a black marginal line; a small speck on vein 2 before margin, from which proceeds a trace of a dusky outer line. Beneath silky whitish, with green tint by transparency. Expanse, $30 \mathrm{~mm}$.

Type.-Female, Cat. No. 15703, U.S.Nat.Mus.; Suapure, Venezuela, April, 1899 (E. A. Klages).

\section{EULEPIDOTIS VIRIDISSIMA Bar.}

Palindia viridissima BAR, Ann. Soc. Ent. France (5), vol. 6, 1876, p. 248.

A series from French Guiana is before me, and one specimen from Venezuela.

\section{EULEPIDOTIS CHLORIS Bar.}

Palindia chloris BAR, Ann. Soc. Ent. France (5), vol. 6, 1876, p. 249.

I identify as this a single specimen from Venezuela. Probably only a variety of the preceding, as originally suggested by Bar.

\section{EULEPIDOTIS FOLIUM Schaus.}

Palindia folium Schaus, Ann. Mag. Nat. Hist. (8), vol. 7, 1911, p. 61.

The type and two other specimens from Costa Rica are before me.

\section{EULEPIDOTIS ILYRIAS Cramer.}

Phalaena Bombyx ilyrias Cramer, Pap. Exot., vol. 1, 1779, p. 15, pl. 10, fig. E.

Phalaena ilyraria FABRICIUs, Ent. Syst., vol. 3, 1792, pp. 2, 138.

Eulepidotis illyiaria HüBNER, Verz. bek. Schmett., 1816, p. 291.

Palindia ilyrias Guenée, Spec. Gen., vol. 6, 1852, p. 278.

Palindia ilyrias Walker, Cat. Brit. Mus., Lep. Het., part 12, 1857, p. 859.

Palindia ilyrias Bar, Ann. Soc. Ent. France (5), vol. 6, 1876, p. 246.

A series is before me from the Guianas and Costa Rica, showing the two customary varieties with a small and a large brown patch on the fore wing. 


\section{EULEPIDOTIS SYLPHA Dyar.}

This will be more fully described in my fourth paper on Mexican Lepidoptera to be published in the present volume of the Proceedings of the United States National Museum. The two types are before me - a male from Costa Rica and female from Mexico.

\section{EULEPIDOTIS GLAUCOPASA Dyar.}

This also will be considered in my fourth Mexican paper. Five specimens are before me, all from Mexico.

\section{EULEPIDOTIS SCHEDOGLAUCA, new species.}

Grass green; fore wing with the costa very narrowly brown; lines slender, brown, straight, slightly widened and luteous filled on costa, converging a little in the direction of tornus; costal area of hind wing shaded with orange; outer margin entire, without modification or marginal mark; a spot of raised scales before the margin, black within, silver without; tornus and fringe at submedian touched with orange; a terminal black line, touched with silver; fringe interlined with green and tipped with brown. Beneath greenish, washed over with brown; two curved brown lines on fore wing. Expanse, $27 \mathrm{~mm}$.

Cotypes.-Male and female, Cat. No. 15705, U. S. Nat. Mus.; St. Jean, Maroni River, French Guiana, July, 1904 (W. Schaus).

Another male from Aroa, Venezuela (Schaus collection), is a little larger, otherwise identical.

\section{EULEPIDOTIS HOLOCLERA, new species.}

Green; forewing with pale brown edge of costa linear; lines slender, brown, straight, without costal widening, but minute light dots at costa, converging a little in the direction of tornus; fringe green. Hindwing with large orange area at apex and costa; a small red-brown incision at submedian fold, followed by a narrow terminal line and one minute black dot. Beneath green at the bases of both wings, shaded with rusty outwardly; forewing with one faint outer line or clouded brown area. Expanse, 32-34 mm.

Cotypes.-One male, two females, Cat. No. 15706, U. S. Nat. Mus.; St. Jean, Maroni River, French Guiana, July, 1904 (W. Schaus).

Though so nearly related to $E$. schedoglauca, the present species has no hair tufts on the hind tibiæ of the male. These tufts are large and conspicuous in schedoglauca.

\section{EULEPIDOTIS STIGMASTICTA Dyar.}

This will be more fully mentioned in my fourth Mexican paper. Two cotypes, both females from Mexico, are before me.

EULEPIDOTIS CROCEIPARS, new species.

Fore wing green; the three lines of a duller shade, slightly converging in the direction of tornus; fringe tipped with brown. Hind- 
wing bright orange; a green ray on each side of submedian fold, the upper one spreading out on the margin and inclosing a small raised silvery spot with black scales on the edges; margin entire, with three silvery and one black dots in the green area. Abdomen green at base, orange on terminal half. Below green near bases of the wings, then orange, the apex of forewing shaded with brown. Male without tuft on hind tibia. Expanse, $40 \mathrm{~mm}$.

Type.-Male, Cat. No. 15707, U. S. Nat. Mus.; Rio Janeiro, Brazil (Schaus collection).

\section{EULEPIDOTIS ATALANTA Bar.}

Palindia atalanta BAR, Ann. Soc. Ent. France (5), vol. 6, 1876, p. 249.

This species is not before me, but should be readily recognizable from Bar's excellent figure.

\section{EULEPIDOTIS ERINA, new species.}

Green; abdomen green above at the base, fuscous posteriorly. Fore wing mossy green; three crossbands double, brown-filled, wavy or subcrenulate, close and all terminating perpendicular to inner margin, curved on costal half; inner line angularly bent in the middle; a fourth wavy shaded subterminal line; a row of irregular blotches through cell outwardly to margin; a row of terminal white dots; fringe brown. Hindwing blackish fuscous; a green ray before submedian fold and triangular patch on margin beyond it, containing a blackish speck; a narrow outer curved line running near margin toward tornus. Beneath shaded with fuscous brown, especially outwardly; both wings with two curved fuscous bands. Expanse, $27 \mathrm{~mm}$.

Type.-Female, Cat. No. 15708, U. S. Nat. Mus.; St. Jean, Maroni River, French Guiana, April, 1904 (W. Schaus).

\section{EULEPIDOTIS DELECTA Schaus.}

Palindia delecta Schaus, Ann. Mag. Nat. Hist. (8), vol. 7, 1911, p. 59.

The type and another specimen from Costa Rica are before me.

\section{EULEPIDOTIS SERPENTIFERA Brabant.}

Palindia serpentifera Brabant, Le Nat. (2), vol. 22, 1909, p. 178.

Four specimens from French Guiana are before me, identified by Mr. Schaus.

\section{EULEPIDOTIS EZRA Druce.}

Palindia ezra Druce, Biol. Cent.-Amer., Lep. Het., vol. 2, 1898, p. 499.

Described from Mexico. I have five specimens from there, one from Costa Rica, one from Panama, and two from Venezuela. Possibly it is not more than racially distinct from hebe Möschler of the Antilles. The two are certainly very close.

\section{EULEPIDOTIS HEBE Möschler.}

Palindia hebe Möschler, Abh. Senck. Nat. Ges., vol. 14, 1886, p. 195.

Eight specimens are before me from Cuba. 


\section{EULEPIDOTIS STRIÆPUNCTA Herrich-Shäffer.}

Palindia strixpuncta Herrich-Schäffer, Corr.-Bl., zool.-min. ver. Regensb. vol. 22,1869 , p. 153 .

Palindia variabilis Möschler, Abh. Senck. Nat. Ges., vol. 14, 1886, p. 194.

Palindia var. obscura Möschler, Abh. Senck. Nat. Ges., vol. 14, 1886, p. 195.

Closely allied to hebe, apparently a degenerate offshoot from it. The colors are dulled and very variable, the white costal ornamentation obsolete, the markings of hind wing reduced. I have five specimens from Cuba.

\section{EULEPIDOTIS PERDUCENS Walker.}

Palindia perducens Walker, Cat. Brit. Mus., Lep. Het., part 15, 1858, p. 1767.

Described from Jamaica. I have no specimens.

EULEPIDOTIS AFFINIS Schaus.

Palindia affinis Schaus, Ann. Mag. Nat. Hist. (8), vol. 7, 1911, p. 60.

The continental representative of the Antillean perducens. I have seven from Costa Rica, one from Panama, and one from Venezuela.

\section{EULEPIDOTIS JULIANATA Stoll.}

Phalaena Geometra julianata Stoll, Suppl. Cramer's Pap. Exot., 40, pl. viii, fig. 4, 1791 (written juliata in index, p. 383).

Palindia julianata Guenée, Spec. Gen., vol. 6, 1852, p. 277.

Palindia egala Walker, Cat. Brit. Mus., Lep. Het., part 33, 1865, p. 807.

Palindia julianata Bar, Ann. Soc. Ent. France (5), vol. 6, 1876, p. 5.

Palindia julianata Butler, Ent., 1892, p. 190.

Unknown to Guenée, but well figured by Bar. Butler runs this in with juncida Guenée=aglaura Bar, wrongly, I think. He does not mention mabis Guenée in this connection, as he had evidently misidentified the name (see Dyomyx fumata Felder and Rogenhofer), apparently from following Walker. ${ }^{1}$ Seventeen specimens are before me from French Guiana, one from Venezuela, and one from Mexico, the latter an aberration with purple shading filling in the basal space up to the central line.

\section{EULEPIDOTIS JUNCIDA Guenée.}

Palindia juncida Guenée, Spec. Gen., vol. 6, 1852, p. 277.

Palindia mabis Guenée, Spec. Gen., vol. 6, 1852, p. 277.

Patindia thecloides Walker, Cat. Brit., Mus., Lep. Het., part 12, 1857, p. 851.

Palindia aglaura BAr, Ann. Soc. Ent. France (5), vol. 6, 1876, p. 7.

Palindia julianata, vars. juncida and aglaura Butler, Ent., 1892, p. 190.

This species varies in the amount of purple shading. In typical juncida there is none, except in the terminal space; it gradually increases as a general smoky suffusion of the pale parts until the wing is wholly and uniformly shaded (var. mabis). Walker apparently misidentified mabis, as he describes his thecloides, which is the same thing, immediately after. Bar recognized the variability of the species, but did not recognize it as juncida Guenée, which he 
refers to as unknown to him. Butler also recognized the variation, but went a step too far by including also julianata Stoll. I have 135 specimens before me from Brazil, the Guianas, Venezuela, Panama, Costa Rica, and Mexico.

\section{EULEPIDOTIS GEMINATA Packard.}

Palindia geminata Packard, First Rep. Peabody Acad. Sci., 1869, p. 64.

Palindia regina Druce, Ann. Mag. Nat. Hist. (6), vol. 4, 1889, p. 93.

I have four specimens before me from Ecuador, Colombia, and Costa Rica. Dr. A. S. Packard's type was collected by the Smithsonian Expedition to South America in 1867 "on the route from Quito across the Andes, down the Napo River, and along the river Maranon." Druce described from Ecuador.

EULEPIDOTIS FORTISSIMA, new species.

Shining white; abdomen dull ocher on posterior half; head and collar brown. Forewing with broad, dark brown band, widest on costa and running to tornus, contiguous on its lower half to the outer brown area; this is broad, bent toward base in middle, terminated by a double line, dull ocher filled below; a vague pale submarginal shade, preceded by a darker area. Hindwing yellowish, with a white ray on either side of submedian fold; a large black patch at apex; a short tail on outer margin, preceded by a black spot with white dash on one side and marginal white line on the other, preceded by a brownish area with scattered blâck scales, and before this a very short brown line at end of outer white ray. Expanse, 40-44 mm.

Cotypes.-Two males, one female, Cat. No. 15709, U. S. Nat. Mus.; Rio Janeiro, Brazil (Schaus collection); Omai, British Guiana (Schaus collection); Juan Vinas, Costa Rica, February (W. Schaus).

Near dominicata Guenée, but distinctly larger and the ornamentation of the hind wing different.

EULEPIDOTIS DOMINICATA Guenée.

Palindia dominicata Guenée, Spec. Gen., vol. 6, 1852, p. 276.

Described from Brazil. I have specimens from there, the Guianas, Venezuela and Costa Rica. This species has been recorded from the United States, ${ }^{1}$ but on what material is unknown to me. I should rather expect rectimargo or electa to occur with us, as these species are in my experience much more abundant than dominicata and extend farther north.

\section{EULEPIDOTIS PERSIMILIS Guenée.}

Palindia persimilis Guenée, Spec. Gen., vol. 6, 1852, p. 276.

I have a single specimen from Brazil, the type-locality. 


\section{EULEPIDOTIS NICAEA Druce.}

Palindia nicæa Druce, Ann. Mag. Nat. Hist. (7), vol. 5, 1900, p. 518.

This is unknown to me, but appears from the description close to the following.

\section{EULEPIDOTIS TELIGERA Brabant.}

Palindia teligera Brabant, Le Nat. (2), vol. 23, 1910, p. 31.

Palindia vivida Dognin, Het. nouv. l'Amer. du sud, vol. 6, 1912, p. 20.

Brabant described from Venezuela, Dognin from Paraguay. I have five specimens from Venezuela agreeing perfectly with the descriptions of both authors.

\section{EULEPIDOTIS ARGYRITIS Butler.}

Eulepidotis argyritis Butler, Trans. Ent. Soc. Lond., 1879, p. 29.

Described from Brazil. I have one from Venezuela and eight from Mexico, one of the latter compared with Butler's type by Mr. Schaus.

\section{EULEPIDOTIS SUPPURA Dyar.}

This will be described more fully in my fourth Mexican paper. I have six cotypes from Mexico and Venezuela.

\section{EULEPIDOTIS ELECTA Dyar. ${ }^{1}$}

This will be mentioned more in detail in my forthcoming Panama report. Twenty-six specimens are before me from Venezuela, Panama, Costa Rica, and Mexico.

\section{EULEPIDOTIS RECTIMARGO Guenée.}

Palindia rectimargo Guenée, Spec. Gen., vol. 6, 1852, p. 276.

Thirty-five specimens are before me from Brazil, Paraguay, the Guianas, Venezuela, Panama, Costa Rica, and Mexico.

\section{EULEPIDOTIS METAMORPHA, new species.}

Very similar to rectimargo, differing principally in the direction of the crossband, which runs obliquely from tornus to costa at basal third and is joined completely to the base by the costal dash. Hind wing with the mark fainter, its preceding dash very distinct. Expanse, $30 \mathrm{~mm}$.

Type--Male, Cat. No. 15110, U. S. Nat. Mus.; Matanzas, Cuba, November, 1902 (W. Schaus).

\section{EULEPIDOTIS SANTAREMA Walker.}

Palindia santarema WALker, Cat. Brit. Mus., Lep. Het., part 33, 1865, p. 806.

This species is not before me.

\section{EULEPIDOTIS CANDIDA Bar.}

Palindia candida BAR, Ann. Soc. Ent. France, (5), vol. 6, 1876, p. 8.

This is not before me, but Bar's figure leaves no room for doubt as to the identity of this form. 


\section{EULEPIDOTIS ALBATA Felder and Rogenhofer.}

Palindia albata Felder and Rogenhofer, Reise Novara, Lep., 1872, pl. 111, fig. 1.

Palindia magdalensis BAR, Ann. Soc. Ent. France, (5), vol. 6, 1876, p. 434.

Ten specimens are before me from French Guiana.

\section{EULEPIDOTIS OUOCCO, new species.}

Small; costo-subapical orange spot large; costa alternating orange and metallic blue with a white spot near the middle; sub-basal line with white central spot; marginal line widely expanded in the middle. Hind wing with costal half whitish, the rest brown with faintly indicated purplish outer half-band. Fringe white, interrupted below the middle by a small dark speck. Expanse, $15 \mathrm{~mm}$.

Type.-Cat. No. 15711, U. S. Nat. Mus.; St. Jean, Maroni River, French Guiana, July, 1904 (W. Schaus).

\section{EULEPIDOTIS GUTTATA Felder and Rogenhofer.}

Palindia guttata Felder and Rogenhofer, Reise Novara, Lep., 1872, pl. 111, fig. 3.

Palindia micra BAR, Ann. Soc. Ent. France (5), vol. 6, 1876, p. 433.

Forty-three specimens are before me from French Guiana, Panama, Costa Rica, and Nicaragua.

\section{EULEPIDOTIS PERLATA Guenée.}

Palindia perlata Guenée, Spec. Gen., vol. 6, 1852, p. 279.

Palindia spectabilis Walker, Cat. Brit. Mus., Lep. Het., part 15, 1858, p. 1767.

Forty-one specimens are before me from Brazil, French Guiana, Panama, Costa Rica, and Nicaragua. Very close to guttata, but differing in many details. The two silvery spots are not infrequently confluent, occasionally forming a band, which in one specimen is narrow, almost as in albata.

\section{EULEPIDOTIS DETRACTA Walker.}

Palindia detracta Walker, Cat. Brit. Mus., Lep. Het., part 12, 1857, p. 847.

Described from Brazil. I have eight from Brazil and Paraguay.

EULEPIDOTIS TESTACEICEPS Felder and Rogenhofer.

Palindia testaceiceps Felder and Rogenhofer, Reise Novara, Lep., 1872, pl. 111, fig. 16.

Palindia albula BAr, Ann. Soc. Ent. France, (5), vol. 6, 1876, p. 20.

I have nine specimens from Venezuela, Panama, and Costa Rica. EULEPIDOTIS ALABASTRARIA Hübner.

Eulepidotis alabastraria HÜBNER, Verz. bek. Schmett., 1816, p. 291.

Eulepidotis alabastriaria HüBNER, Zutr. exot. Schmett., 1818, p. 22, figs. 311-312. Palindia punctangulata WAlker, Cat. Brit. Mus., Lep. Het., part 12, 1857, p. 848.

Palindia alabastraria Butlen, Ent., 1892, p. 190.

Thirty-six specimens are before me from Brazil, French Guiara, Venezuela, Panama, Costa Rica, and Mexico. This name was introduced into the North American faunal list by Hulst as a Geometrid, ${ }^{1}$ lately corrected by Swett. ${ }^{2}$ 
EULEPIDOTIS PULCHELLA Bar.

Palindia pulchella BAr, Ann. Soc. Ent. France (5), vol. 6, 1876, p. 245.

This is not before me. Butler makes it a synonym of alabastraria, but none of my series of that species show the little bar close to margin of hind wing seen in Bar's figure, so I hold the name separate.

\section{EULEPIDOTIS HEMILEUCA Guenée.}

Palindia hemileuca Guenée, Spec. Gen., vol. 6, 1852, p. 275.

One specimen from Brazil is before me.

EULEPIDOTIS MICROLEUCA, new species.

As in hemileuca Guenée, except that the basal white space of fore wing is filled in with black and brown scales nearly down to vein 1 . In hemileuca this space is white with a black spot on costa and dot below. Expanse, $29 \mathrm{~mm}$.

Type.-Male, Cat. No. 15712, U. S. Nat. Mus.; Rio Janeiro, Brazil (Schaus collection).

This may be an aberration of hemileuca, but my series of both forms is so limited that I can form no idea of the range of variation.

\section{EULEPIDOTIS VINCENTIATA Stoll.}

Phalæna Geometra vincentiata Stoll, Suppl. Cramer's Pap. Exot., 1791, p. 39, pl. 8, fig. 3.

Palindia vincentiata BAr, Ann. Soc. Ent. France (5), vol. 6, 1876, p. 9.

This is not before me.

\section{EULEPIDOTIS ORNATA Bar.}

Palindia ornata BAR, Ann. Soc. Ent. France (5), part 6, 1876, p. 11.

I have seen no specimens of this species.

\section{EULEPIDOTIS CAUDATA Herrich-Schäffer.}

Palindia caudata Herrich-Schäffer, Exot. Schmett., 1853, fig. 136.

Palindia caudata WALker, Cat. Brit. Mus., part 12, 1857, p. 850.

Described from Surinam. I have a single specimen from Panama.

\section{EULEPIDOTIS HERMURA Schaus.}

Palindia hermura Schaus, Journ. N. Y. Ent. Soc., vol. 7, 1898 (June), p. 119.

Palindia evadens Druce, Biol. Cent.-Amer., Lep. Het., vol. 2, 1898 (August), p. 500 .

Thirteen specimens are before me from Mexico, Costa Rica, and Venezuela.

\section{EULEPIDOTIS MODESTULA Herrich-Schäffer.}

Palindia modestula Herrich-Schäffer, Corr.-bl. zool.-min. Ver. Regensb., vol. 22,1869 , p. 153.

Palindia modestula Möschler, Abh. nat. Senck. Ges., vol 14, 1886, p. 193.

I have eight specimens from Cuba. 


\section{EULEPIDOTIS MICCA Druce.}

Palindia micca Druce, Biol. Cent.-Amer., Lep. Het., vol. 1, 1889, p. 319.

Eleven specimens are before me from Mexico, Costa Rica, and Venezuela. This is the continental form of modestula HerrichSchäffer.

\section{UNPLACED SPECIES.}

\section{PALINDIA PRIMULINA Druce.}

Palindia primulina Druce, Ann. Mag. Nat. Hist., (7), vol. 5, 1900, p. 518.

Evidently a peculiar and characteristic species, unlike anything known to me. The following is Mr. Druce's description:

Male.-Head, antennæ, collar, tegulæ, thorax and abdomen pale primrose-color; the under side of the thorax, abdomen, and legs white. Primaries and secondaries pale primrose-yellow; primaries, the costal margin edged with white, three curved chromeyellow bands cross the wing from the costal to the inner margin, the first two bands nearest the base, the third beyond the cell; the marginal line white, with minute black dots; the fringe chrome-yellow; secondaries with a few metallic scales near the anal angle, above which is a short chrome-yellow line; the under side of both wings pale primrose-yellow.

Expanse, 1 inch.

Hab.-Colombia, Valparaiso (Mus. Druce).

\section{PALINDIA REFLEXA Herrich-Schäffer.}

Palindia reflexa Herrich-Schäffer, Corr.-Blatt zool.-min. Ver. Regensb., vol. 22, 1869, p. 154.

Easily to be recognized by the very peculiar secondary sexual character of the male, a round, white, hairy lappet on the costa above. I have seen nothing at all approaching such a structure. The following is Herrich-Schäffer's description:

114) reflexa HS. 489/625. foem.-449/1047 mas.-Kleiner als corinna, Hfl auf R 3 sehr schwach geeckt. Rostbraun, Vfl mit 2 ganz geraden, gegen den IR divergirenden QStreifen, von $1 / 3$ und $2 / 3$ des VR und weisser W der Franzen. Auf den Hfl nur ein weisser Schrägstreif in $\mathrm{Z} 1$ a als innere Begrenzung eines rostrothen Fleckes. Beim kleineren Manne sind beide Streife der Vfl undeutlicher, weniger divergirend, der VR aber hinter der Mitte in einen grossen, halbscheibenförmigen, weissen, rothbraungewimperten Lappen nach oben umschlagen.

Recently Mr. Schaus and the writer, in considering the identification of Herrich-Schäffer's name, havie concluded that it is probably not a Palindia at all, or even a Noctuid, but is an earlier name for Paridnea holophæalis Ragonot, a Pyralid of the subfamily Chrysauginæ.

\section{PALINDIA STRIATARIA Cramer.}

Phalæna Geometer striataria Cramer, Pap. Exot., vol. 4, 1782, p. 125, pl. 355, fig. F. Palindia striata Guenée, Spec. Gen., vol. 6, 1852, p. 278.

Palindia striatia Herrich-ScHÄFfer, Corr.-Blatt zool.-min. Ver. Regens., vol. 22, 1869, p. 153.

Unknown to Guenée (1852), who placed it in Palindia from his interpretation of Cramer's figure. Also unknown to Walker, ${ }^{1}$ who follows Guenée. Herrich-Schäffer had a specimen from Cuba which 
he describes at some length. Bar, overlooking Herrich-Schäffer's work, considers striataria "une Palindidæ bien douteuse." 1 The species is very strongly marked and should be easily recognizable.

\section{PALINDIA SCITA Walker.}

Palindia scita WALKer, Char. undes. Lep. Het., 1869, p. 39.

Sir George Hampson has kindly drawn my attention to this description. It appears to represent a form quite unknown to me. No locality is given.

\section{Genus DYOMYX Guenée.}

Dyomyx Guenée, Spec. Gen., vol. 6, 1852, p. 281. Type cimolia Guenée (first species); cimolia, here designated.

Dyomix Bar, Ann. Soc. Ent. France (5), vol. 6, 1876, p. 436.

Table of the species.

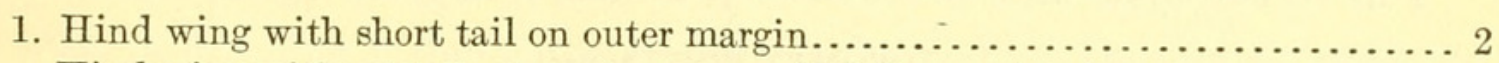

Hind wing without tail, at most wavy or slightly angulated................ 5

2. Discal mark narrow, lunate; white mark on inner margin situated beyond the

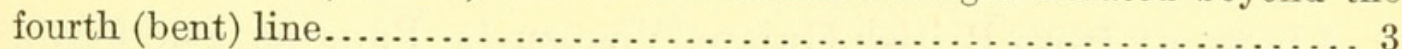

Discal mark wide, oval; white mark on inner margin, if present, following the third (straight) line.

\section{西}

3. Larger, browner; median line of hind wing bordered with orange; submarginal silver line slight................................ albistriga Schaus.

Smaller, grayer; median line of hind wing not distinctly bordered with orange; submarginal silvery line distinct...................... egista Bar.

4. Larger, browner; white mark on inner margin distinct........ consequens Dyar. Smaller, grayer; mark on inner margin faint, yellowish....... merricki Holland. Larger, grayer; no light mark on inner margin.. fumata Felder and Rogenhofer.

5. Fore wing without eye-spot.................. inferior Herrich-Schäffer. Fore wing with round eye-spot above inner margin $6 \ldots \ldots \ldots \ldots \ldots \ldots \ldots 6$

6. Three inner lines straight, oblique............................ 7

These lines wavy or broken.................................... 14

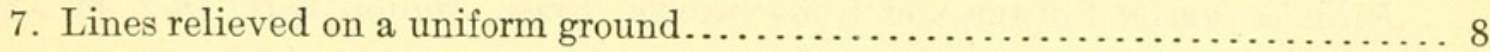

A solid dark shade between mid and inner lines..................... 12

8. Fore wing with terminal dark line relieved by narrow white or yellow lines on each side; median line of hind wing reduced to a dash................ 9

Terminal dark line relieved only by faint pale shades.................. 10

9. Fore wing uniform purplish; lines with yellow edges............. guenei Bar. Fore wing purple-blue on inner half; lines without yellowish edges

. janus Bar.

Subterminal line faint or obsolete................................ 11

11. Mesial line of hind wing beneath even; pale line before terminal line of forewing above, dotted .............................................. Schaus.

Mesial line of hind wing beneath crenulate; pale subterminal line not dotted... 12

12. Ocellus large; reniform free from mesial line; inner line of hind wing parallel to

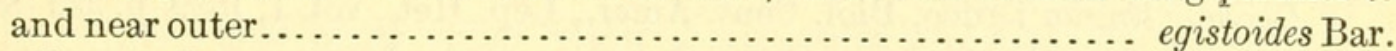

Ocellus small; reniform contiguous to mesial line; inner line of hind wing remote from outer line, curved, obsolescent................... herberta Dyar.

13. Shade between mid and inner lines uniform in width......... jonesi Schaus.

This shade cut off above inner margin.................... zates Druce. 
14. Median area with dark filling between the lines....................... 15

Median area without dark filling............................... 17

15. Dark area from inner to outer line and continued in a patch to outer margin

ora Dyar.

Dark area confined between the inner and median lines............... 16

16. Hind wing olive yellow with dark brown angled area from base; marginal mark

large, silvery, with black striæ..................... juno Möschler.

Hing wing brown; marginal mark slight, rather inconspicuous.. volcanica Schaus.

17. Hing wing with subocellate black spots on outer margin................ 18

Hind wing without such spots, all fuscous with a narrow orange terminal edge

ancea Cramer.

18. Small; hind wing with single marginal ocellus............. placida Schaus.

Large; hind wing with three marginal black ocellate dots....... cimolia Guenée.

DYOMYX ALBISTRīGA Schaus.

Palindia albistriga Schaus, Ann. Mag. Nat. Hist. (8), vol. 7, 1911, p. 58.

I have the type and two other specimens, all from Costa Rica.

\section{DYOMYX EGISTA Bar.}

Dyomix egista BAR, Ann. Soc. Ent. France (5), vol. 6, 1876, p. 439.

I have six from British Guiana,Venezuela, Panama, and Costa Rica.

DYOMYX CONSEQUENS Dyar.

This will be more fully described in my fourth Mexican paper. I have five cotypes from Mexico, Panama, and Venezuela.

DYOMYX MERRICKI Holland.

Palindia merricki Holland, Ent. News, vol. 13, 1902, p. 172.

Palindia merricki Dyar, Proc. Ent. Soc. Wash., vol. 14, 1912, p. 194.

Nine specimens are before me, all from Venezuela. The species was described from Pennsylvania, presumably from a stray specimen.

\section{DYOMYX FUMATA Felder and Rogenhofer.}

Palindia fumata Felder and Rogenhofer, Reise Novara, Lep., 1872, pl. 111, fig. 17.

Eulepidotis mabis Butler (not Guenée), Trans. Ent. Soc. Lond., 1879, p. 29.

Palindia mabis Druce (part, not Guenée), Biol. Cent.-Amer., Lep. Het., vol. 1, 1889 , p. 317.

This is not before me. Butler misidentified Guenée's mabis, apparently by following Walker's arrangement in the British Museum. Druce quoted the synonymy from Butler, though he probably had the true mabis before him.

\section{DYOMYX INFERIOR Herrich-Schäffer.}

Palindia inferior Herrich-Schäffer, Corr. Bl., zool.-min. Ver. Regensb., vol. 22, 1869 , p. 153.

Dyomyx lineata Druce, Biol. Cent.-Amer., Lep. Het., vol. 1, 1889, p. 320 (female).

Seven specimens are before me from Brazil, Panama, Costa Rica, and Mexico. Druce figures as male and female two different species. I restrict the name to the female figured in the Biologia, plate 29, fig. 25 . 


\section{DYOMYX GUENEI Bar.}

Dyomix guenei BAR, Ann. Soc. Ent. France (5), vol. 6, 1876, p. 442.

This is not before me. Bar's figure seems excellent.

\section{DYOMYX MEGALOPS Guenée.}

Dyomyx megalops Guenée, Spec. Gen., vol. 6, 1852, p. 282.

I have not seen specimens. Guenée's figure is very sketchy, but probably recognizable.

\section{DYOMYX JANUS Bar.}

Dyomix janus BAR, Ann. Soc. Ent. France (5), vol. 6, 1876, p. 441.

Not known to me in nature.

\section{DYOMYX OCALA Schaus.}

Dyomyx ocala Schaus, Ann. Mag. Nat. Hist. (8), vol. 7, 1911, p. 61.

The male type is before me. Mr. Schaus had associated with it another specimen as the female, but I consider this specimen to belong to the next species.

\section{DYOMYX EGISTOIDES Bar.}

Dyomix egistoides BAr, Ann. Soc. Ent. France (5), vol. 6, 1876, p. 440.

A single female from Costa Rica is before me, agreeing well with Bar's characterization. It is mentioned above under ocala.

\section{DYOMYX HERBERTA, new species.}

Dyomyx lineata Druce male (not female), Biol. Cent.-Amer., Lep. Het., 1889, pl. 29, fig. 24 .

Brown, with faint purple irridescence over whole of fore wing, very faint on hindwing; lines slender, straight; subbasal half line, to vein 1, parallel to inner line, which runs from inner fifth of costa to inner third of inner margin; mesial line a little broader and less rigid than the other, slightly bent at median vein, touching inner side of small black ocellus on vein 1, which has white pupil, orange ring and brown outer ring; reniform vague, rather narrow, lunate, defined by inner and outer curved lines; outer line bent above vein 7, lost below 2, a brown marginal line, edged on both sides by pale lines. Hindwing with a line across disk, running close to margin, twice angled but not dentate, followed by a narrow dull orange streak and a blue-gray powdery area, which runs upward to about vein 5 ; two distant narrow white marginal lines; a small black dot between them opposite the outer angle of the middle line. This spot has an orange edging but is scarcely ocellate. Beneath a common mesial curved crenulate line, the hind wing with a straight shaded arc within it. Expanse, $43 \mathrm{~mm}$.

Cotypes.-Two females, No. 15713, U. S. Nat. Mus.; St. Jean, Maroni River, French Guiana, April, 1904 (W. Schaus); Sixola River, Costa Rica, March, 1907 (W. Schaus). 
DYOMYX JONESI Schaus.

Dyomyx jonesi Schaus, Journ. N. Y. Ent. Soc., vol. 6, 1898, p. 120.

Dyomyx oblrquata Schaus, Ann. Mag. Nat. Hist. (8), vol. 7, 1911, p. 62.

I have the unique types of jonesi from Brazil and obliquata from Costa Rica. Both are males and almost identical.

\section{DYOMYX ZATES Druce.}

Dyomyx zates Druce, Biol. Cent.-Amer., Lep. Het., vol. 2, 1898, p. 500.

Two specimens are before me from Costa Rica.

DYOMYX ORA Dyar.

To be more fully described in my fourth Mexican paper. I have a female from Mexico and another from Panama. This is not improbably an ornate variety of $D$. cimotia Guenée.

\section{DYOMYX JUNO Möschler.}

Dyomyx juno Möschuer, Abh. Senck. Nat. Ges., vol. 14, 1886, p. 197.

This is not before me.

\section{DYOMYX VOLCANICA Schaus.}

Dyomyx volcanica Schaus, Journ. N. Y. Ent. Soc., vol. 6, 1898, p. 119.

The type and three other Mexican specimens are before me and two from Costa Rica.

\section{DYOMYX PLACIDA Schaus.}

Dyomyx placida Schaus, Ann. Mag. Nat. Hist. (7), vol. 8, 1901, p. 39.

Six specimens are before me from Mexico, including the type. In one specimen the whole median space is ocherous.

\section{DYOMYX CIMOLIA Guenèe.}

Dyomyx cimolia Guenèe, Spec. Gen., vol. 6, 1852, p. 282.

Dyomyx pavo Walker, Cat. Brit. Mus., Lep. Het., part 15, 1858, p. 1769.

Two specimens from Mexico are before me.

\section{DYOMYX ANCEA Cramer.}

Phalæna Noctua ancea Cramer, Pap. Exot., vol. 4, 1782, p. 72, pl. 324, fig. G.

Platyja ${ }^{1}$ ancea HÜBNer, Verz. bek. Schmett., 1816, p. 268.

Dyomyx ancea Guenée, Spec. Gen., vol. 6, 1852, p. 282.

Dyomyx ancea Walker, Cat. Brit. Mus., Lep. Het., vol. 12, 1857, p. 854.

Unknown to me except by Cramer's figure. The figure is bad, but seems nearest to cimotia Guenée of anything before me. I have so few cimolia that I can not form a good idea of the extent of its variation.

1 The type of Platyja Hübner must be taken to be umminea Cramer (first species), designated by Hampson (Moths of India, vol. 2, 1894, p. 539). 


\section{$2 \mathrm{BHL}$ Biodiversity Heritage Library}

Dyar, Harrison G. 1914. "The noctuid moths of the genera Palindia and Dyomyx." Proceedings of the United States National Museum 47(2046), 95-116. https://doi.org/10.5479/si.00963801.47-2046.95.

View This Item Online: $\underline{\text { https://www.biodiversitylibrary.org/item/32860 }}$

DOI: https://doi.org/10.5479/si.00963801.47-2046.95

Permalink: https://www.biodiversitylibrary.org/partpdf/31713

\section{Holding Institution}

Smithsonian Libraries

\section{Sponsored by}

Smithsonian

\section{Copyright \& Reuse}

Copyright Status: NOT_IN_COPYRIGHT

This document was created from content at the Biodiversity Heritage Library, the world's largest open access digital library for biodiversity literature and archives. Visit BHL at https://www.biodiversitylibrary.org. 